\title{
CHARACTERIZATION OF YELLOW RUST (PUCCINIA STRIIFORMIS WESTEND.): REVIEW
}

\author{
Liga Feodorova-Fedotova ${ }^{1,2}$, Biruta Bankina ${ }^{1}$ \\ ${ }^{1}$ Latvia University of Life Sciences and Technologies, Latvia \\ ${ }^{2}$ Latvian Plant protection research centre Ltd., Latvia \\ liga.f.fedotova@laapc.lv
}

\begin{abstract}
Yellow rust caused by Puccinia striiformis is a significant wheat disease in cereal growing areas worldwide. On average, yellow rust can cause $50 \%$ big yield damages resulting in economic losses. Yellow rust damages wheat leaves, leaf sheaths, awns, and glumes. Puccinia striiformis is divided into four lineages - P. striiformis sensu stricto, P. pseudostriiformis, P. striiformoides, P. gansensis. Different races of yellow rust have been determined. After 2000 three new aggressive races - 'Warrior', 'Kranich' and 'Triticale aggressive' have been identified. New races are characterized by shorter latent period, extended spore germination and tolerance to a high temperature in comparison with the races determined before 2000. These characteristics allowed the new races to replace races dominant before 2000. Yellow rust is a biotrophic heteroecious fungus with a complicated life cycle. For successful development, Puccinia striiformis requires cereals as primary hosts and Berberis spp. as alternate hosts. The history of studies regarding yellow rust is more than two hundred years old but only in 2010 the ecidiospores of yellow rust were found on the alternate host Berberis spp. Two types of resistance - seedling (or all-stage) resistance and adult plant resistance (APR) were discovered. Since 2000 multiple severe epidemics of yellow rust have been observed in cereal growing areas with warmer climate. In recent years, the incidence of yellow rust in Latvia has increased. Particular studies about the biology, distribution, and races of Puccinia striiformis in Latvia are necessary. This article summarizes the information about the classification, biology and harmfulness of the yellow rust.
\end{abstract}

Key words: Puccinia striiformis, races, diversity, control.

\section{Introduction}

Yellow rust Puccinia striiformis Westend. (Pst) is one of the most harmful wheat pathogens in cereal growing areas present in all continents except Antarctica (Chai et al., 2014). Chen (2005) reported that at early infection on susceptible varieties yield losses can reach $100 \%$ but on average yield losses can vary $10-70 \%$ during the epidemics. The amount of damaged yield is measured in millions of tons and causes significant financial losses (Wan et al., 2004; Wellings, 2007). Wellings (2011) concluded that $P$ st is the most significant threat to wheat production.

Pst is a biotrophic heteroecious fungus (Chen et al., 2014; Hovmøller et al., 2016). Cereals as primary hosts and Berberis spp. as alternate hosts are necessary for successful development of yellow rust (Jin, Szabo, \& Carson, 2010). Yellow rust has been investigated since the 18th century (Stubbs, 1985) but only after 2000 harmful epidemics were observed. Nowadays new aggressive races of $P$ st have been identified.

Yellow rust is widespread in major wheat producing regions like the Middle East, China, US, Australia (Chen, 2005; Yahyaoui et al., 2002; Wan et al., 2004; Wellings, 2007). Hassebrauk (1965, cited by Hovmøller et al., 2011) reported that 320 grass species from 50 genera can be infected with $P s t$ with artificial or natural infection. Yellow rust can cause epidemics on barley in Europe and America (Brown et al., 2001; Macer \& Driessche, 1966). Epidemics on rye are not frequent nowadays (Stubbs, 1985).

Wheat infection at the seedling stage usually results in reduced root growth, plant height, and dry matter production, size and number of flowering spikes, and the size of grains also is less than expected. Infection during anthesis reduces root weight and the amount of yield (Wellings, 2011). Yield losses in wheat from Pst infections are usually the result of reduced grain number per spike, low test weight and reduced grain quality (Roelfs, Singh, \& Saari, 1992).

Information about the incidence of Pst and influence on the yield in Latvia is not clear. Eglitis (1938) reported that yellow rust in Latvia is harmful only on wheat. On barley, until 1938 one observation was registered in Priekuli but on rye yellow rust was not observed. In 1970-80, periodic observations of the Pst were made in the breeding fields in Stende (Strazdina, 2017, personal communication). Systematic observations about the incidence of $P s t$ in Latvia have not been performed, sporadic observations of the pathogen have been made (Bankina, Jakobija, \& Bimsteine, 2011). In 2010 severe infection was observed on winter wheat in Stende. In 2015, extensive infection was observed on winter and spring wheat in Kurzeme near the coast of the Baltic Sea. In 2016 yellow rust was observed in the whole territory of Latvia (Strazdina, 2017, personal communication).

The aim of this article is to summarize the information from literature about Puccinia striiformis Westend. with emphasis on classification, biology, and harmfulness of the yellow rust.

\section{Materials and Methods}

Monographic method has been used for this study. Scientific literature from different countries 
regarding to wheat pathogen causing yellow rust Puccinia striiformis Westend, its biology, evolution and distribution has been summarized.

\section{Results and Discussion}

Symptoms

Yellow rust damages wheat leaves, leaf sheaths, awns and glumes. Chlorotic flecks on primary host leaves can be observed $6-8$ days after inoculation (Chen et al., 2014). In these flecks, $0.4-0.7 \mathrm{~mm}$ long and $0.1 \mathrm{~mm}$ wide uredinial pustules that can contain thousands of dikaryotic uredospores are located. Uredospores visually remind yellow to orange powder, each spore has an ellipse to obovoid form with the size of $24.5 \times 21.6 \mu \mathrm{m}$. Sporulation starts from 12 to 14 days after inoculation (Chen et al., 2014), depending on temperature, moisture, and host resistance. During the development, yellow rust can be observed as orange, narrow stripes usually between leaf veins. Approaching the host senescence or when the temperature is high, telia are produced. Telia usually are pulvinate to an oblong form, $0.2-0.7$ $\mathrm{mm}$ long, $0.1 \mathrm{~mm}$ wide. Teliospores are dark brown, rounded, flattened at the vertex from $24-31$ until $56-$ $65 \mu \mathrm{m}$ long and from $11-14$ - until $25-29 \mu \mathrm{m}$ wide (Chen et al., 2014).

During severe epidemics, awns and glumes can be infected. On resistant plants, Pst appears as small flecks with chlorosis, necrosis and limited spore production or do not show any visual symptoms. On seedlings, Pst does not appear as narrow stripes between leaf veins but covers all leaf surface as small spots (Chen et al., 2014).

On the upper side of the alternate host Berberis spp. leaves yellow to orange flask-shaped pycnia with oblong-shaped pycniospores can be observed. On the lower side of the alternate host Berberis spp. leaves sunflower-shaped aecia with spherical-shaped aeciospores can be found.

\section{Taxonomy}

The common names of Puccinia striiformis Westend. are yellow rust, stripe rust, and glume rust. In literature, the first time yellow rust was mentioned in 1777 by Gadd but taxonomically named as Uredo glumarum in 1827 by Johann Carl Schmidt (Eriksson \& Henning, 1896 cited by Stubbs, 1985).

Several synonyms of Pst have been used in the past like Uredo glumarum J.C. Schmidt, Trichobasis glumarum Lév, Puccinia neglecta Magnus, Puccinia tritici Oerst, Puccinia glumarum (J.C. Schmidt) Erikss \& Henning, Puccinia lineatula Bubák, Dicaeoma glumarum (J.C. Schmidt) Arthur \& Fromme, Puccinia rubigo-vera (Erikss) Carleton, Pleomeris glumarum
(J.C.Schmidt) Syd, Puccinia striformoides M. Abbasi, Hedjar \& M. Scholler ${ }^{1}$.

Puccinia striiformis is classified in kingdom Fungi, phylum Basidiomycota, class Urediniomycetes, order Uredinales, family Pucciniaceae, genus Puccinia. Puccinia is notable genera in Pucciniaceae that includes more than 4,000 different species (Cummins \& Hiratsuka, 2003 cited by Sørensen, 2012).

Pst infects different species of wheat - common wheat Triticum aestivum L., durum wheat Triticum turgidum var. durum L., cultivated emmer wheat Triticum dicoccum Schrank, wild emmer wheat Triticum dicoccoides Korn, triticale x Triticosecale, rye Secale cereale L., barley Hordeum vulgare L. and pasture grass species like Elymus canadensis L., Leymus secalinus Hochst, Agropyron spp. Garetn, Hordeum spp. L., Phalaris spp. L. and Bromus unioloides Kunth (Chen et al., 2014).

$P s t$ isolates can differ by morphological characters and peculiarities of an epidemic. Eriksson (1894 cited by Hovmøller et al., 2011) based on host specialization divided Puccinia striiformis in five special forms (formae speciales): P. striiformis f. $\mathrm{sp}$. tritici on wheat, $P$. striiformis f. sp. hordei on barley, P. striiformis f. sp. secalis on rye, P. striiformis f. sp. elymi on Elymus spp., and P. striiformis f. sp. agropyron on Agropyron spp. Extra formae speciales were divided: P. striiformis f. sp. dactylidis (Psd) on orchard grass (Dactylis glomerata L.) (Manners, 1960; Tollenaar, 1967), P. striiformis f. sp. poae (Psp) on Kentucky bluegrass (Poa pratensis L.) (Tollenaar, 1967), P. striiformis f. sp. leymi on Leymus secalinus (Georgi) Tzvel. (Niu et al., 1991 cited by Chen et al., 2014) and P. striiformis f. sp. pseudo-hordei (Psp-h) on Hordeum spp. in Australia (Wellings, 2007).

Liu \& Hambleton (2010) based on DNA sequence polymorphisms and different morphological qualities divided Puccinia striiformis into four lineages and declared them as diverse species. The first lineage called P. striiformis sensu stricto infects Triticeae, host range - Aegilops, Elymus, Hordeum, Triticum (Chen et al., 2014). The second lineage P. pseudostriiformis previously named as $P$. striiformis $\mathrm{f}$. $\mathrm{sp}$. poae infects Poa spp., the third lineage $P$. striiformoides previously known as $P$. striiformis var. dactylidis) infects Dactylis spp. The fourth lineage - Puccinia gansensis was found in China and infects Achnatherum inebrians (Liu \& Hambleton, 2010; Chen et al., 2014).

It is considered that the center of origin of yellow rust is Transcaucasia (Hassebrauk, 1965, cited by Hovmøller et al., 2011) where yellow rust was present on grasses and later spread to other territories. The west part of China and Central Asia (Ali et al., 2010) also is considered to be the center of origin. Isolates

\footnotetext{
1 Species Fungorum. From: CABI databases. [Online] [viewed 8 March 2018]. Available: http://www.speciesfungorum.org/GSD/ GSDspecies.asp?RecordID $=227064$
} 
taken in these territories produce more telia and have a higher genetic diversity (Chen et al., 2014) with frequent recombination (Vallavielle-Pope et al., 2012 cited by Chen et al., 2014) than isolates from other territories. Yellow rust has the clonal population structure in Europe, Australia and America (Hovmøller et al., 2016), resulting from asexual reproduction. The evolution of sex as an ancestral trait was used in the searches of origin (Hovmøller et al., 2011). Despite many researches and recent discoveries, the center of origin of Pst and diversity of population have not been clarified yet. Research in this field continues and information about the race composition and DNA diversity in separate geographical regions will improve scientific knowledge about the pathogen diversity.

\section{Races}

The most significant traits in relation to gene and genotype diversity are virulence and race. In the process of mutation (genetic variation) new alleles and genotypes are derived. Flor (1956 cited by Sørensen, 2012) defined the gene-for-gene hypothesis that was the basics for race identification. Gene-for-gene hypothesis is based on host resistance genes related to pathogen avirulence genes, if they make pairs, the host is resistant and vice versa.

Between 1975 and 2000 mutations that resulted in the loss of avirulence were determined 16 times (Hovmøller \& Justesen, 2007).

The concept of races - a pattern of pathogen responses to inoculation onto differential lines, was proposed by Allison \& Isenbeck (1930 cited by Hovmøller et al., 2011).

The first race of yellow rust was identified in 1979 (Wellings \& McIntosh, 1990). Detailed research about races in Europe and the USA started in the late 1960s (Line \& Qayoum, 1992, cited by Hovmøller et al., 2011) when several epidemics of yellow rust were recorded on wheat in California (Tollenaar \& Houston, 1967). Since the 1960s up to 300 samples of yellow rust are collected and race-analyzed every year (Chen et al., 2009). Similar researches were carried out in Australia (Wellings, 2007), China (Wan et al., 2004; Chen et al., 2009), India (Prashar et al., 2007) and South Africa (Boshoff, 2002). Since 1990s, studies of Pst population structure and diversity have been successfully applied because of the development of biotechnology and molecular marker techniques (Hovmøller et al., 2011).

Since 2000 epidemics of yellow rust have been observed in warmer cereal growing areas where Pst had not been found previously. In 2000 yellow rust caused epidemics in the South, Central and Eastern United States. In these territories, yellow rust has been rare because of high temperatures during the growing season (Chen et al., 2000). These epidemics were caused by pathogen isolates that were different from isolates identified before 2000 in terms of AFLP and virulence phenotype (Markell \& Milus, 2008).

In 2000 in Central Europe, an aggressive strain of yellow rust PstS2 was determined (Hovmøller et al., 2011). PstS2 is related to PstS1, these strains were found in many areas within five continents. In the Mediterranean / Middle East region on several wheat cultivars epidemics were observed but most of the cultivars stayed resistant (Abbasi et al., 2004). Between 2000 and 2002 fast and broad spread of yellow rust was observed (Hovmøller et al., 2008). To compare these strains with North American races and typical northwestern European races (races typical before 2010) different virulence phenotypes were found but the evolutionary origin was common (Hovmøller et al., 2011). After 2011 new races - 'Warrior', 'Kranich' and 'Triticale aggressive' were identified. In Europe, yellow rust race 'Triticale aggressive' was detected in 2006 on the island of Bornholm in the Baltic Sea. 'Warrior' replaced races found before 2011, 'Kranich', 'Triticale aggressive' were found in certain regions and/or crop types. All three races had spread in large areas within one or a few years. Races of non-European origin have been found in different areas 1-2 years after the first detection (Hovmøller et al., 2016).

Only a few of the European races recognized between 2000 and 2010 were found from 2011 to 2014. New aggressive races have different molecular characteristics, higher genetic diversity in comparison with the existing European population. New races produce a lot of telia which indicates that aggressive races have evolved from sexual populations (Hovmøller et al., 2016). The composition of races changes quickly; research about the incidence of specific races in different geographic regions is necessary to understand the possibilities of development and distribution of new races.

\section{Resistance}

Host resistance plays an important role in successful disease control. Development of new resistant cereal varieties is the main task for plant breeders and scientists (Singh et al., 2004). The largest Pst research centres are located in Denmark, France, UK, USA, China and Mexico. In Eurowheat database http://www.eurowheat.org data about $P$. striiformis virulence dynamics in Europe and disease control measures are published (Jørgensen et al., 2010). Resistance to Pst as a genetic trait has been known since 1905 when Biffen crossed yellow rust immune and susceptible wheat species (Hovmøller et al., 2011). During 1980s in European wheat breeding programs Yr17-resistance was established. 
Yr17 resistant cultivars were introduced in the early 1990s and stayed resistant to yellow rust until 1994. Then a new Yr17 - virulent race with different AFLP fingerprint appeared in the UK (Justesen, Ridout, \& Hovmøller, 2002).

Yellow rust can infect susceptible wheat varieties at any plant growth stage while the plant parts are green. There are two main types of resistance - seedling (or all-stage) resistance and adult plant resistance (APR) (Chen et al., 2014).

Seedling resistance is race specific (Johnson, 1992). It is qualitatively inherited and expressed during all plant growth stages. Seedling resistance is controlled by single genes with major effects or simple combinations of single genes. Changes in single-genes increase the virulence in Pst populations. Single genes resistant to yellow rust are called $Y r$-genes. 41 from 55 catalogued $\mathrm{Yr}$ genes refer to seedling resistance and 14 to APR genes (Chen et al., 2014).

Adult plant resistance is commanded by one or several quantitative trait loci. In prevalence with some exclusions, APR is described as quantitatively inherited, non-race specific and provides durable resistance (Chen, 2005, 2013). During the seedling stage, plants with APR are susceptible to yellow rust, resistance comes effective at post-seedling development (Boyd, 2006). APR shows better yield protection if it starts in early growth stages in comparison with resistance starting from flag leaf emergence (Chen et al., 2014). APR is influenced by temperature and crop nutritional status; high nitrogen level can provoke more serious disease expression (Chen, 2005, 2013). High-temperature adult plant resistance (HTAP) becomes more effective with increasing temperature (Chen, 2005).

Plant resistance and its reaction - virulence/ avirulence to pathogen isolates are traditionally evaluated on seedlings. For assessment of virulence or avirulence by phenotyping method differential sets are used. They consist of different wheat varieties with known resistance genes. Inoculation of wheat varieties with spores of $P s t$ is performed under controlled conditions. Two different scales - from full resistance (specific resistance genes are present) to full susceptibility (specific resistance genes are not present) are used to assess the level of leaf damages. The $0-9$ scale (McNeal, 1971, cited by Chen, 2005) is widely used in Europe, North America, Syria, and Lebanon (Chen et al., 2014). The 0 - 4 scale (Gassner \& Straib, 1932a, b cited by Chen et al., 2014) is used in Australia (Wellings \& McIntosh, 1990), China (Chen et al., 2009), India (Prashar et al., 2007), South Africa (Boshoff et al., 2002) and Pakistan (Ali et al., 2010). Scales are divided by ranging from no visible symptoms, chlorosis and necrosis to density of sporebearing pustules (Chen, 2005). If the interaction is compatible, it is scored as a high infection type, if interaction is incompatible - a low infection type on differential lines (Hovmøller et al., 2017). The present differential set for Pst race identification is composed of 20 wheat lines (Chen et al., 2009). In different regions various differential lines are used (Bayles et al., 2000; Wan et al., 2007; Wellings, 2007), depending on commercial wheat cultivars but race nomenclature system has stayed similar since the 1960s.

\section{Life cycle}

Until 2010 it was assumed that Pst is an autoecious micro-cyclic pathogen. In the last century efforts to identify the alternate host of Pst by infecting different plant species with germinating teliospores have failed (Jin et al., 2010) and detailed information about the sexual host of yellow rust stayed a mystery (Wellings, 2011). Berberis spp. and Mahonia spp. were suspected to be the alternate hosts of Puccinia striiformis because of related rusts found on these plants (Mains, 1933, cited by Stubbs, 1985). The sexual stage of yellow rust on Berberis spp. and Mahonia spp. was described by Jin, Szabo, \& Carson (2010). He observed pycnia on Berberis spp. leaves when aecia were developed on the bottom side of the leaf. Jin, Szabo, \& Carson (2010) proved that Berberis spp. is the alternate host of yellow rust by successful infection of wheat with aeciospores from $B$. chinensis that resulted in uredinia. Molecular analysis - real-time polymerase chain reaction and DNA sequence - affirmed the identity of P. striiformis (Jin et al., 2010). It has been found that alternate hosts are barberry - Berberis chinensis, B. koreana, B. holstii, B. vulgaris, B. shensiana, B. potaninii, B. dolichobotrys, etc. Wang \& Chen, 2013 proved that Oregon grape Mahonia aquifolium can also serve as an alternate host of Puccinia striiformis (Chen et al., 2014). Alternate hosts help pathogen to survive between cropping seasons. As the global distribution of Berberis spp. is not clear, it is difficult to predict the influence of sexual reproduction on the dynamics in P. striiformis populations at global scale (Hovmøller et al., 2011). Although the sexual stage of Pst has been proved (Jin et al., 2010), the influence of sexual reproduction on Pst dynamics (Hovmøller et al., 2011) and origin of epidemics is not known.

Previously it was assumed that yellow rust is a low-temperature pathogen and is distributed in temperate climate zones with cool and moist weather conditions (Chen et al., 2014) or in warm territories with cold nights (Stubbs, 1985). To compare with other rusts, Pst is more sensitive to meteorological conditions such as moisture and air temperature that play a significant role in germination and infection processes (Chen et al., 2014).

A suitable temperature for germination of uredospores is from $8{ }^{\circ} \mathrm{C}$ to $12{ }^{\circ} \mathrm{C}$ (Vallavieille-Pope 
et al., 1995) and comfortable temperature for infection is $8{ }^{\circ} \mathrm{C}$ (Dennis, 1987). Chen et al., 2014 observed that the minimum temperature for germination of uredospores is $0{ }^{\circ} \mathrm{C}$ and maximum $20-26{ }^{\circ} \mathrm{C}$.

For successful inoculation moisture on leaf surface is necessary. Relative humidity should reach more than $50 \%$ for sporulation to occur (Zadoks, 1961; Rapilly \& Fournet, 1968, both cited by Chen et al., 2014). Cereal density influences moisture level between the plants. The development of yellow rust is slower if the length of the day is shorter or the light intensity is lower (Wellings, McIntosh, \& Hussain, 1988). Stubbs (1985) reported that light intensity during the seedling tests should be over 10,000 lux. Yellow rust is sensitive to UV light and air pollution that negatively influences the germination of uredospores (Sharp, 1967, cited by Chen et al., 2014).

Pst can migrate long distances and spread spores with the help of wind (Chen et al., 2014; Hovmøller et al., 2016; Hovmøller et al., 2017) and human-assisted transport (Brown \& Hovmøller, 2002). If the winter is severe, spores of yellow rust can die and wind is the only way how to spread (Hovmøller, Justesen, \& Brown, 2002). Uredospores can spread thousands of kilometers from the primary infection areas (Chen et al., 2014). Stubbs (1985) reported that uredospores have spread more than 1,200 km from northern France to Algeria by wind blasts. Justesen, Ridout, \& Hovmøller (2002) by comparing AFLP lineages found that migration of Pst occurred between the UK, Germany, France and Denmark, and some Pst populations in Denmark arrived from France and/or Germany by the wind. In the US Pacific Northwest yellow rust infected spring wheat from winter wheat and opposite (Chen, 2005). Pst can stay on wild grass species.

Milus, Seyran, \& McNew, 2006 reported that Pst has adapted to high temperatures. New yellow rust races are characterized by shorter latent period and $2-3$ times bigger spore production per day, tolerance to high air temperature, extended aggressiveness in high and low temperatures (Milus, Kristensen, \& Hovmøller, 2009) in comparison with the races identified in Europe and North America before 2000 (Milus et al., 2009). Races with the ability to cause infection faster than before have been found in North America in 2000 (Milus, Seyran, \& McNew, 2006). Only spores of new races can germinate at high temperature (Volin \& Sharp, 1973). At the temperature of $10{ }^{\circ} \mathrm{C}$, during the night and $18^{\circ} \mathrm{C}$ during the day new, aggressive races showed $16 \%$ shorter latent period, $71 \%$ more spores per $\mathrm{mm}^{2}$ of a sporulating lesion and the pathogen grew $18 \%$ faster. At $12{ }^{\circ} \mathrm{C}-$ $28{ }^{\circ} \mathrm{C}$, isolates of new races showed by $26 \%$ shorter latent period, produced $159 \%$ more spores during the day, pathogen grew 18\% faster (Markell \& Milus, 2008; Milus et al., 2009). Hovmøller, Walter, \& Justesen, 2010 defined this aggressive strain as PstS1 (Hovmøller et al., 2008; Markell \& Milus, 2008).

Pst has a complicated life cycle with five various stages (Hovmøller et al., 2011) and it requires an alternate host to complete a full growth cycle (Jin, Szabo, \& Carson, 2010). Uredospores, teliospores and basidiospores infect primary host (Hovmøller et al., 2011) on alternate host pycniospores, and aeciospores of Pst are formed.

Uredospores are dikaryotic and can be formed asexually (Buller, 1950, cited by Rodriguez-Algaba et al., 2017). Each uredinium produces spores over the period of several days and causes epidemics on the primary host. Uredospores can be produced several times during the season. In later host growth stages telia are formed that produce two-celled teliospores. Teliospores have two thick-walled cells each containing diploid in karyogamy formed nucleus. In similar conditions, the capability to develop telia can be different between isolates (Chen et al., 2012).

Teliospores can germinate immediately without a dormancy period. Germinating teliospores through karyogamy meiosis produces haploid basidiospores (Leonard \& Szabo, 2005) that infect alternate host Barberry spp. After a pycnia with pycniospores is formed on the upper side of the leaf. After fertilization a mycelium is formed, it grows through the leaf, and aecia with dikaryotic aeciospores is formed on the lower side of the leaf(Chen et al., 2012). When climatic conditions are favourable - a high level of humidity aecia crack, unclose and exempt aeciospores that can infect gramineous hosts if they are near. The full life cycle can continue for two growing seasons of the primary host (Hovmøller et al., 2011).

\section{Conclusions}

Life cycle of Puccinia striiformis Westend. has changed and it has been revealed only over the last two decades.

New aggressive races of yellow rust have adapted to high temperatures and can spread more effectively in cereal growing areas.

\section{References}

1. Abbasi, M., Hedjaroude, Gh.A., Scholler, M., \& Goodwin, S.B. (2004). Taxonomy of Puccinia striiformis s.1. in Iran. Rostaniha, 5, 71-82. DOI: 10.1016/j.jconhyd.2010.08.009.

2. Ali, M., Ji, W.Q., Hu, Y.G., Baloch, G.M., Zhong, H., \& Wang, C.Y. (2010). Molecular implications from Ssr markers for stripe rust (Puccinia striiformis f. sp. tritici) resistance gene in bread wheat line N95175. Pak. J. Bot., 42(1), 383-390. 
3. Ali, S., Leconte, M., Walker, A.S., Enjalbert, J., \& de Vallavieille-Pope, C. (2010). Reduction in the sex ability of worldwide clonal populations of Puccinia striiformis f. sp. tritici. Fungal Genetics and Biology, 47(10), 828-838. DOI: 10.1016/j.fgb.2010.07.002.

4. Bankina, B., Jakobija, I., \& Bimsteine, G. (2011). Peculiarities of wheat leaf disease distribution in Latvia. Acta Biol. Univ. Daugavp., 11(1), 47-54. DOI: 10.5586/aa.2005.059.

5. Bayles, R., Flath, K., Hovmøller, M., \& de Vallavieille-Pope, C. (2000). Breakdown of the Yr17 resistance to yellow rust of wheat in northern Europe. Agronomie, 20, 805-811.

6. Boshoff, W.H.P., Pretorius, Z.A., \& van Niekerk, B.D. (2002). Establishment, distribution, and pathogenicity of Puccinia striiformis f. sp. tritici in South Africa. Plant Disease, 86(May), 485-492.

7. Boyd, L.A. (2006). Can the durability of resistance be predicted?, 2526(July), 2523-2526. DOI: 10.1002/ jsfa.

8. Brown, W.M., Hill, J.P., \& Velasco, V.R. (2001). Barley yellow rust in North America. Annual Review of Phytopathology, 39, 367-384.

9. Brown, J.K.M., \& Hovmøller, M.S. (2002). Aerial dispersal of fungi on the global and continental scales and its consequences for plant disease. Science, 297, 537-541.

10. Chai, Y., Kriticos, D.J., Beddow, J.M., Duveiller, E., \& Sutherst, R.W. (2014). Puccinia striiformis. HarvestChoice, September, 1-7.

11. Chen, J., Chu, C., Souza, E.J., Guttieri, M.J., Chen, X., Hu, S. ... Zemetra, R. (2012). Genome-wide identification of QTL conferring high-temperature adult-plant (HTAP) resistance to stripe rust (Puccinia striiformis f. sp. tritici) in wheat. Molecular Breeding, 29(3), 791-800. DOI: 10.1007/s11032-011-9590-x.

12. Chen, W.Q., Wu, L.R., Liu, T.G., Hu, S.C., Jin, S.L., Peng, Y.L., \& Wang, B.T. (2009). Race dynamics, diversity, and virulence evolution in Puccinia striiformis f. sp tritici, the causal agent of wheat stripe rust in China from 2003 to 2007. Plant Disease, 93(11), 1093-1101. DOI: 10.1094/pdis-93-11-1093.

13. Chen, W., Wellings, C., Chen, X., Kang, Z., \& Liu, T. (2014). Wheat stripe (yellow) rust caused by Puccinia striiformis f. sp. tritici. Molecular Plant Pathology, 15(5), 433-446. DOI: 10.1111/mpp.12116.

14. Chen, X. (2013). High-temperature adult-plant resistance, key for sustainable control of stripe rust. Am.J. Plant Sci. Biotechnol, 4(March), 608-627. DOI: 10.4236/ajps.2013.43080.

15. Chen, X.M. (2005). Review / Synthèse Epidemiology and control of stripe rust [Puccinia striiformis f. sp. tritici] on wheat. Canadian Journal of Botany, 27, 314-337. DOI: 10.1071/ar07045.

16. Chen, X., Moore, M., Milus, E.A., Long, D.L., Line, R.F., Marshall, D., \& Jackson, L. (2000). Wheat stripe rust epidemics and races of Puccinia striiformis f. sp. tritici in the United States in 2000. Plant Disease, $86(1), 39-46$.

17. de Vallavieille-Pope, C., Huber, L., Leconte, M., \& Goyeau, H. (1995). Comparative effects of temperature and interrupted wet periods on germination, penetration, and infection of Puccinia recondita f. sp. tritici and P. striiformis on wheat seedlings. Phytopathology, 85(4), 409-415. DOI: 10.1094/Phyto-85-409.

18. Dennis, J.I. (1987). Temperature and wet-period conditions for infection by Puccinia striiformis f. sp. tritici race 104e137a+. Trans.Br.Mycol., 88(1), 119-121. DOI: 10.1007/BF02879166.

19. Hovmøller, M.S., \& Justesen, A.F. (2007). Rates of evolution of avirulence phenotypes and DNA markers in a northwest European population of Puccinia striiformis f. sp. tritici. Molecular Ecology, 16(21), 46374647. DOI: 10.1111/j.1365-294X.2007.03513.x.

20. Hovmøller, M.S., Justesen, A.F., \& Brown, J.K.M. (2002). Clonality and long-distance migration of Puccinia striiformis f. sp. tritici in north-west Europe. Plant Pathology, 51(1), 24-32. DOI: 10.1046/j.13653059.2002.00652.x.

21. Hovmøller, M.S., Rodriguez-Algaba, J., Thach, T., \& Sørensen, C.K. (2017). Race typing of Puccinia striiformis on wheat. Wheat rust diseases, 1659, 29-40. DOI: 10.1007/978-1-4939-7249-4.

22. Hovmøller, M.S., Sørensen, C.K., Walter, S., \& Justesen, A.F. (2011). Diversity of Puccinia striiformis on cereals and grasses. Annual Review of Phytopathology, 49(1), 197-217. DOI: 10.1146/annurevphyto-072910-095230.

23. Hovmøller, M.S., Walter, S., Bayles, R.A., Hubbard, A., Flath, K., Sommerfeldt, N., ... de VallavieillePope, C. (2016). Replacement of the European wheat yellow rust population by new races from the centre of diversity in the near-Himalayan region. Plant Pathology, 65(3), 402-411. DOI: 10.1111/ppa.12433.

24. Hovmøller, M.S., Walter, S., \& Justesen, A.F. (2010). Escalating threat of wheat rusts. Science, 329(5990), 369. DOI: $10.1126 /$ science.1194925.

25. Hovmøller, M.S., Yahyaoui, A.H., Milus, E.A., \& Justesen, A.F. (2008). Rapid global spread of two aggressive strains of a wheat rust fungus. Molecular Ecology, 17(17), 3818-3826. DOI: 10.1111/j.1365294X.2008.03886.x. 
26. Jin, Y., Szabo, L.J., \& Carson, M. (2010). Century-old mystery of Puccinia striiformis life history solved with the identification of Berberis as an alternate host. Phytopathology, 100(5), 432-435. DOI: 10.1094/ PHYTO-100-5-0432.

27. Johnson, R. (1992). Reflections of a plant pathologist on breeding for disease resistance, with emphasis on yellow rust and eyespot of wheat. Plant Pathology, 41, 239-254.

28. Jørgensen, L.N., Hovmøller, M.S., \& Hansen, J.G. (2010). Euro Wheat.org - A support to integrated disease management in wheat. Outlooks on Pest Management, 21(4), 173-176. DOI: 10.1564/21aug06.

29. Justesen, A.F., Ridout, C.J., \& Hovmøller, M.S. (2002). The recent history of Puccinia striiformis f.sp. tritici in Denmark as revealed by disease incidence and ALFP markers. Plant Pathology, 51(1), 13-23. DOI: 10.1046/j.0032-0862.2001.00651.x.

30. Leonard, K.J., \& Szabo, L.J. (2005). Stem rust of small grains and grasses caused by Puccinia graminis. Molecular Plant Pathology, 6(2), 99-111. DOI: 10.1111/J.1364-3703.2004.00273.X.

31. Liu, M., \& Hambleton, S. (2010). Taxonomic study of stripe rust, Puccinia striiformis sensu lato, based on molecular and morphological evidence. Fungal Biology, 114(10), 881-899. DOI: 10.1016/j. funbio.2010.08.005.

32. Macer, R.C.F., \& Van den Driessche, M. (1966). Yellow rust (Puccinia striiformis Westend.) of barley in England, 1960-65. Agric. Sci., 67, 255-265.

33. Manners, J.G. (1960). Puccinia striiformis Westend. var. Dactylidis var. nov. Trans.Br.Mycol., 43(1), 6568.

34. Markell, S.G., \& Milus, E.A. (2008). Emergence of a novel population of Puccinia striiformis f. sp. tritici in Eastern United States, Phytopathology 98(6), 632-639. DOI: 10.1093/PHYTO-98-6-0632.

35. Milus, E.A., Seyran, E., \& McNew, R. (2006). Aggressiveness of Puccinia striiformis f. sp. tritici isolates in the South-Central United States. Plant Disease, 90(7), 847-852.

36. Milus, E.A., Kristensen, K., \& Hovmøller, M.S. (2009). Evidence for increased aggressiveness in a recent widespread strain of Puccinia striiformis f. sp. tritici causing stripe rust of wheat. Phytopathology, 99(1), 89-94. DOI: 10.1094/PHYTO-99-1-0089.

37. Prashar, M., Bhardwaj, S.C., Jain, S.K., \& Datta, D. (2007). Pathotypic evolution in Puccinia striiformis in India during 1995-2004. Australian Journal of Agricultural Research, 58, 602-604.

38. Rodriguez-Algaba, J., Sørensen, C.K., Labouriau, R., Justesen, A.F., \& Hovmøller, M.S. (2017). Genetic diversity within and among aecia of the wheat rust fungus Puccinia striiformis on the alternate host Berberis vulgaris. Fungal Biology, 121(6-7), 541-549. DOI: 10.1016/j.funbio.2017.03.003.

39. Roelfs, A.P., Singh, R.P., \& Saari, E.E. (1992). Rust Diseases of Wheat: Concepts and methods of disease management. Mexico, D.F.: CIMMYT.

40. Singh, R.P., William, H.M., Huerta-Espino, J., \& Rosewarne, G. (2004). Wheat rust in Asia: meeting the challenges with old and new technologies. Proceedings of the 4th International Crop Science Congress, (October 2004), 1-13. Retrieved March 10, 2018, from: http://www.cropscience.org.au/icsc2004/pdf/141_ singhrp.pdf.

41. Sørensen, C.K. (2012). Infection biology and aggressiveness of Puccinia striiformis on resistant and susceptible wheat. Unpublished doctoral dissertation, Universitu of Aarhus, Research Center Flakkebjerg, Denmark.

42. Stubbs, R.W. (1985). The cereal rusts. Orlando, Florida: Academic Press.

43. Tollenaar, H., \& Houston, B.R. (1967). A study on the epidemiology of stripe rust Puccinia striiformis West., in California. Canadian Journal of Botany, 45, 291-307.

44. Tollenaar, H. (1967). A comparison of Puccinia striiformis f. sp. poae on bluegrass with P. striifromis f. $\mathrm{sp}$. tritici and f. sp. dactylidis. Phytopathology, 57, 418-420.

45. Volin, R.B., \& Sharp, E.L. (1973). Physiologic specialization and pathogen aggressiveness in stripe rust. Phytopathology, 63, 699-703.

46. Wan, A.M., Chen, X.M., \& He, Z.H. (2007). Wheat stripe rust in China. Australian, 56, 605-619. DOI: 10.1071/AR06142.

47. Wan, A., Zhao, Z., Chen, X., He, Z., Jin, S., Jia, Q., ... Yuan, Z. (2004a). Wheat Stripe Rust Epidemic and Virulence of Puccinia striiformis f. sp. tritici in China in 2002. Plant Disease, 88(8), 896-904. DOI: 10.1094/PDIS.2004.88.8.896.

48. Wang, M.N., \& Chen, X.M. (2013). First report of oregon grape (Mahonia aquifolium) as an alternate host for the wheat stripe rust pathogen (Puccinia striiformis f. sp. tritici) under artificial inoculation. Plant Disease, 97, 839. DOI: 10.1094/PDIS-09-12-0864-PDN. 
49. Wellings, C.R., \& McIntosh, R.A. (1990). Puccinia striiformis f. sp. tritici in Australasia: pathogenic changes during the first 10 years. Plant Pathology, 39, 316-325.

50. Wellings, C.R., McIntosh, R.A., \& Hussain, M. (1988). A new source of resistance to Puccinia striiformis f. sp. tritici in spring wheats. Plant Breeding, 100, 88-96.

51. Wellings, C.R. (2007). Puccinia striiformis in Australia: A review of the incursion, evolution, and adaptation of stripe rust in the period 1979-2006. Australian Journal of Agricultural Research, 58(6), 567-575. DOI: 10.1071/AR07130.

52. Wellings, C.R. (2011). Global status of stripe rust: A review of historical and current threats. Euphytica, 179(1), 129-141. DOI: 10.1007/s10681-011-0360-y.

53. Yahyaoui, A.H., Hakim, M.S., el Naimi, M., \& Rbeiz, N. (2002). Evolution of physiologic races and virulence of Puccinia striiformis on wheat in Syria and Lebanon. Plant Disease, 86(5), 499-504. DOI: 10.1094/PDIS.2002.86.5.499. 